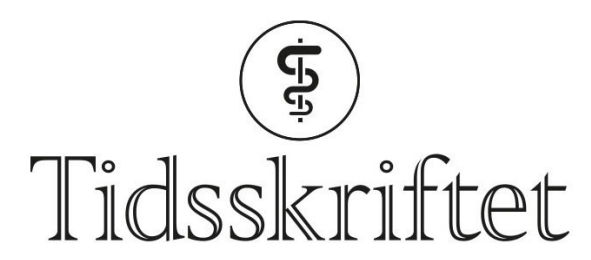

DEN NORSKE LEGEFORENING

\title{
En kvinne i 40-årene med bekkensmerter og uklare MR-funn
}

NOE Å LAERE AV

\section{MARTE KAREN BRATTÅS}

Medisinsk avdeling

Haraldsplass Diakonale Sykehus

Marte Karen Brattås er lege i spesialisering i indremedisin.

Forfatteren har fylt ut ICMJE-skjemaet og oppgir ingen interessekonflikter.

\section{HILDE KOLLSETE GJELBERG}

Avdeling for patologi

Haukeland universitetssjukehus

Hilde Kollsete Gjelberg er spesialist i patologi med fagområder lymfom- og hematopatologi samt gastrointestinal patologi.

Forfatteren har fylt ut ICMJE-skjemaet og oppgir ingen interessekonflikter.

\section{VERNESA DIZDAR}

Medisinsk avdeling

Haukeland universitetssjukehus

Vernesa Dizdar er spesialist i indremedisin og i gastroenterologi og er ph.d.-stipendiat.

Forfatteren har fylt ut ICMJE-skjemaet og oppgir ingen interessekonflikter.

\section{NILS VETTI}

Radiologisk avdeling

Haukeland universitetssjukehus

og

Klinisk institutt 1

Universitetet i Bergen

Nils Vetti er spesialist i radiologi og førsteamanuensis.

Forfatteren har fylt ut ICMJE-skjemaet og oppgir ingen interessekonflikter.

\section{LIV-TURID BERTELSEN}

Revmatologisk avdeling

Haukeland universitetssjukehus

Liv-Turid Bertelsen er spesialist i revmatologi.

Forfatteren har fylt ut ICMJE-skjemaet og oppgir ingen interessekonflikter.

\section{HÅKON REIKVAM}

E-post: hakon.reikvam@med.uib.no

Medisinsk avdeling

Haukeland universitetssjukehus

og

Klinisk institutt 2

Universitetet i Bergen 
Hos en kvinne med bekkensmerter ble det ved radiologisk undersøkelse påvist et unormalt funn i beinmargen. Diagnostisering av tilstanden som hadde gitt henne plagene, krevde tverrfaglig tilnærming.

Pasienten var en kvinne i 40-årene med hypertensjon og psoriasis. Hun hadde gjennomgått en langsgående ventrikkelreseksjon (gastric sleeve) og var utredet for mangeårige smerter i nedre del av rygg, med funn av prolaps i lumbosakralcolumna på MR to år tidligere. De siste månedene hadde pasienten hatt $\varnothing$ kende smerter og ubehag i bekkenet med bilateral utstråling til underekstremitetene. Smertene var ilende og av en annen karakter enn de hun kjente fra sin prolaps. De økte ved belastning, men var også til stede i hvile. Fastlegen hadde tolket symptomene som relatert til prolapsen og hadde henvist pasienten til behandling hos fysioterapeut samt anbefalt smertelindring med NSAID-preparater og opiater. Pasienten hadde en fysisk krevende jobb og var nå sykmeldt på grunn av det aktuelle. Som ledd i utredningen hos fastlegen var det gjort ny MR-undersøkelse av bekken og lumbosakralcolumna. Den viste småflekket signalforandring i beinmarg, mest uttalt i bekkenringen og hofteregionen (figur 1).

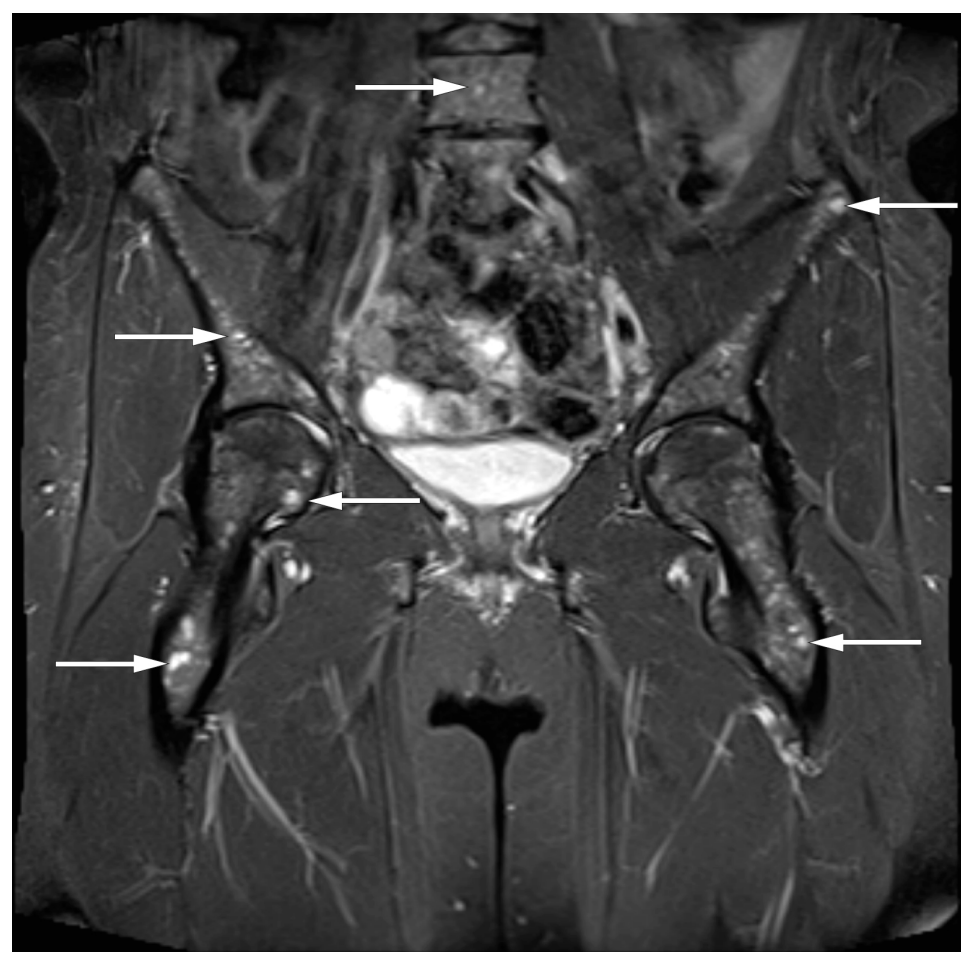

Figur 1 Koronalt, fettsupprimert, T2-vektet MR-bilde med småflekkede, diffust utbredte signalavvik $i$ beinmarg (piler), mest uttalt i bekkenskjelettet og proksimale femur, men også synlig lumbalt.

Smerter i nedre del av rygg og i bekken/hofter er svært vanlig i befolkningen, og opptil 8o \% vil månedlig oppleve slike smerter eller plager i en eller annen form (1).

Differensialdiagnostikk ved smerter i nedre del av rygg og bekken er bred. Bildediagnostikk blir ofte gjort som ledd i å utelukke alvorlige bakenforliggende tilstander (2).

Kvinnen ble henvist til hematologisk poliklinikk med spørsmål om beinmargssykdom. Pasienten fortalte om økende slapphet, men benektet feber, nattesvette eller vekttap. Klinisk undersøkelse avdekket ingen patologi. CRP var lett forhøyet til $14 \mathrm{mg} / \mathrm{l}(<5)$. Andre orienterende laboratorieprøver, inkludert senkningsreaksjon, var normale. Proteinelektroforese viste ingen monoklonale bånd, og immunglobuliner viste normale nivåer. Ytterligere radiologisk bildediagnostikk ble ikke utført på dette tidspunktet.

Pasienten hadde hvilesmerter, opplevde at smertene hadde en annen karakter enn tidligere, og MR-undersøkelse viste patologisk signal i relasjon til beinmarg i affisert område. Myelomatose debuterer ofte med ryggsmerter, og andre hematologiske sykdommer kan 
også gi smerter og signalavvik ved MR-undersøkelse $(3,4)$. Det var ikke sett monoklonalt bånd ved proteinelektroforese, noe som gjorde myelomatose lite sannsynlig.

Spondyloartritt kan ha varierende forløp, og senkningsreaksjon og CRP trenger ikke være forhøyet, men det var ved MR ikke beskrevet forandringer i ileosakralledd som ved spondyloartritt. Infeksiøs tilstand som osteomyelitt ble vurdert lite sannsynlig på grunn av sykehistorie, god allmenntilstand og kun lett forhøyet CRP. Aktuell differensialdiagnose var malign prosess, med skjelettmetastaser som det mest sannsynlige. Typisk lokalisasjon for metastaser er i lange rørknokler, bekken og columna (5). Pasienten hadde en uavklart tilstand med smerter, slapphet og patologisk funn ved MR-undersøkelse av bekkenskjelettet. Biopsi kan i slike tilfeller være avklarende.

Funn på MR reiste primært mistanke om hematologisk eller metastatisk sykdom. Det ble derfor utført beinmargsaspirat og -biopsi. Aspirasjon av beinmarg viste en lett cellefattig marg med få megakaryocytter, men god modning i myelopoese på 62 \% (25-62 \%) og erytropoese på $21 \%$ (10-35\%), og det var ingen umodne celler eller plasmacelleekspansjon. Samlet tydet dette på god beinmargsfunksjon, uten holdepunkt for primær hematologisk sykdom eller infiltrasjon av beinmargsfremmede celler som kunne reise mistanke om malign sykdom eller skjelettmetastaser. Etter en uke forelå svar fra beinmargsbiopsien, som viste en lett cellefattig beinmarg med hematopoetiske celler i om lag 30-40 \% av snittflaten. Spredt i margrommene var det flere velavgrensete ansamlinger av celler med rikelig eosinofilt cytoplasma og avlange, svakt bøyde kjerner forenlig med epiteloide histiocytter i granulomer. Det var også innslag av noen flerkjernede kjempeceller (figur 2). Det ble ikke påvist fremmedlegememateriale eller nekrose i granulomene. Immunhistokjemisk unders $ø$ kelse med antistoff mot T-cellemark $ø r$ CD3 viste noe $\emptyset$ kt forekomst av T-lymfocytter spredt i margrommene, med fortetning rundt granulomene. Dette ble oppfattet som reaktivt. Det var vanlig mengde plasmaceller i beinmargen, og disse viste vanlig bitypisk fordeling ved farging for lette kjeder (kappa og lambda), forenlig med polyklonale plasmaceller. Polymerasekjedereaksjonstest (PCR) for mykobakterier, inkludert Mycobacterium tuberculosis, var negativ.

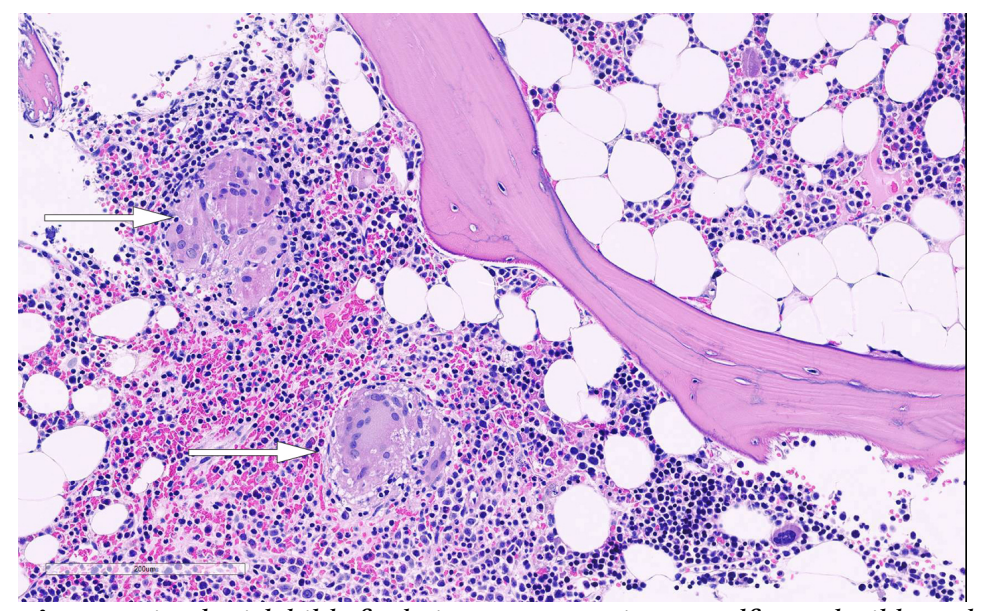

Figur 2 Histologisk bilde fra beinmarg, som viser to velformede, ikke-nekrotiserende granulomer (piler) (hematoksylin- og eosinfarget snitt, ca. 450 ganger forstørrelse).

Det forelå altså en beinmarg med flere epiteloidcellegranulomer uten nekrose, hvilket kan ses ved sarkoidose. Funnet ble vurdert å være forenlig med sarkoidose i beinmarg (ramme 1).

\section{Ramme 1 Diagnostiske kriterier for sarkoidose. Gjengitt etter Heinle og Chang}

(11). 
granulomatøse sykdommer

KLINISKE DIAGNOSEKRITERIER

Erythema nodosum

Hyperkalsiuri

Anemi

Pancytopeni

Arytmi

Hilar adenopati ved røntgen thorax

Uveitt

Spondyloartritt

Eleverte leverprøver

Elevert immunglobulinnivå

Funn i bronkoalveolær skyllevæske

Ved poliklinisk undersøkelse hos revmatolog fire uker senere var det ikke tegn til artritter eller utbrudd av psoriasis. EKG viste normofrekvent sinusrytme. Angiotensinkonverterende enzym (ACE) i blod, en vanlig brukt biomarkør for sarkoidose, var forhøyet til 82 U/1 (13-59). Pasienter med sarkoidose er predisponert for hyperkalsemi, men vår pasient hadde normal kalsiumverdi. Beintetthetsmåling viste verdier innenfor referanseområdet for aldersgruppen. Sarkoidose kan manifestere seg som asymptomatisk uveitt $(6,7)$, og alle pasienter med påvist sarkoidose skal utredes hos øyelege (7). Vår pasient hadde ikke tegn til uveitt.

CT thorax med intravenøs kontrast og høyoppløselig CT-snitt utført seks uker etter svar på beinmargsbiopsi viste mediastinal og hilær lymfadenopati med mikronoduli i lungeparenkymet. Funnet var forenlig med lungesarkoidose grad II, med affeksjon av både mediastinale lymfeknuter og lungeparenkym. Som bifunn var det multiple, små, diffust utbredte, hypodense lesjoner i lever og milt, og det ble derfor gjort CT abdomen med intravenøs kontrast. Denne bekreftet multiple, spredte, små, hypodense lesjoner i alle deler av lever, mest utbredt i høyre leverlapp. Milten var normal.

Radiologiske funn ble vurdert forenlig med sarkoidose med manifestasjon i lunge og lever. Noen uker etter funn på CT thorax ble pasienten undersøkt ved lungepoliklinikk. Hun hadde ingen symptomer fra luftveiene. Spirometri og diffusjonstest viste normal lungefunksjon, og det var ikke funnet indikasjon for behandling av lungesarkoidose.

Det var enda uklart om hennes symptomer kunne forklares av sarkoidose og om det forelå indikasjon for behandling. Positronemisjonstomografi (PET) er en diagnostisk metode for å demonstrere aktiv inflammasjon i organ $(8,9)$, PET/CT med glukoseanalogen ${ }^{18}$ F-FDG kan benyttes ved sarkoidose for å oppdage ukjente organmanifestasjoner og lesjoner tilgjengelig for biopsi (9). PET/CT ble vurdert som en nyttig undersøkelse for å vurdere sykdomsaktivitet relatert til sarkoidose.

Åtte uker etter svar på beinmargsbiopsi ble pasienten undersøkt med ${ }^{18} \mathrm{~F}$-FDG-PET/CT. Undersøkelsen viste $ø$ kt opptak av ${ }^{18} \mathrm{~F}$-FDG relatert til magesekk og høyre colonfleksur. Funnet kunne passe med gastrointestinal manifestasjon av sarkoidose. Koloskopi tre uker senere viste makroskopisk normale funn, og biopsier viste lette reaktive forandringer. Ved gastroskopi var det funn av minimalt prepylorisk erytem, for øvrig makroskopisk normale funn i duodenum. Det ble likevel gjort duodenalbiopsier, og disse viste kronisk betennelse med intraepitelial lymfocytose og subtotal totteatrofi. Det var ikke funn av granulomer (figur 3). Blodprøver verifiserte sterkt positivt funn av IgA-antistoffer mot transglutaminase 2 (anti-TG2) med titer $>250 \mathrm{U} / \mathrm{ml}(<14,9)$, lave jernlagre med ferritin på $11 \mu \mathrm{g} / \mathrm{l}(18-240)$. Vevstyping påviste HLA-DQ2, som er assosiert med cøliaki. Funnene var vurdert forenlig med cøliaki ( ramme 2), selv om det anamnestisk ikke forelå gastrointestinale symptomer. Cøliakidiagnose ble satt tre måneder etter første kontakt ved medisinsk poliklinikk. Hun ble anbefalt å legge om til glutenfritt kosthold. Samtidig startet hun tverrfaglig 
rehabilitering, som fastlege hadde henvist til.

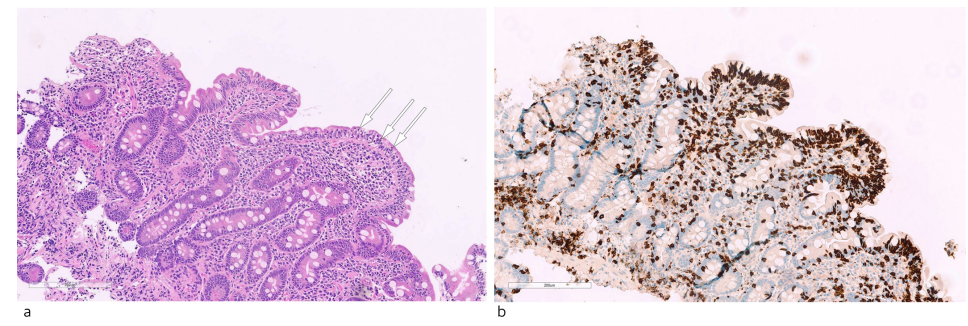

Figur 3 Histologisk bilde fra duodenalslimhinne. a) Duodenalslimhinnebiopsier viste lave, brede totter (subtotal totteatrofi), hyperplasi av kryptlaget og uttalt økning av intraepiteliale lymfocytter $i$ overflateepitelet (piler) (hematoksylin- og eosinfarget snitt, ca. 400 ganger forstørrelse). b) Immunhistokjemisk unders $ø$ kelse med antistoff mot cellemarkør $\mathrm{CD}_{3}$, som farger T-lymfocytter brune (ca. 400 ganger forstørrelse).

\section{Ramme 2 Diagnostiske kriterier for cøliaki. Modifisert etter Catassi og medarbeidere (20). Fire av fem følgende kriterier må vere oppfylt for å stille diagnosen cøliaki: \\ (Typiske) symptomer forenlig med cøliaki Forhøyet nivå av IgA-antistoffer mot transglutaminase 2 (IgA-anti-TG2) Enteropati ved tynntarmsbiopsi Vevstype HLA-DQ2 eller HLA-DQ8 Respons på glutenfri kost}

Tre måneder etter oppstart av glutenfritt kosthold var pasienten til første kontroll hos revmatolog og ved cøliakipoliklinikk. Hun hadde ikke lenger smerter i bekkenet, hadde mer overskudd og var tilbake i full jobb.

Hennes sarkoidose ble sikkert verifisert med affeksjon av beinmarg og lunger, med sannsynlig affeksjon også i lever, selv om funnet her ikke ble verifisert med biopsi. På grunn av lav sykdomsaktivitet uten tegn til alvorlig organmanifestasjon og fordi symptomene gikk over etter omlegging til glutenfri kost, ble det ikke funnet indikasjon for behandling av pasientens sarkoidose.

Seks måneder senere var hun til kontroll hos revmatolog, lungelege og ved cøliakipoliklinikk. Klinisk undersøkelse var upåfallende. Blodprøver viste tilnærmet normalisering av IgA-anti-TG2 med titer 16,9 U/ml $(<14,9)$. Det var ikke tegn til sykdomsaktivitet av lungesarkoidose, med uendrede funn på lungefunksjonstester og høyoppløselig CT, og det forelå ingen dyspné, hoste eller feber. Hun skal ha videre poliklinisk oppfølgning hos revmatolog, lungelege og gastroenterolog.

\section{Diskusjon}

Den aktuelle pasienten hadde ryggsmerter av ny og annen karakter enn hun tidligere hadde hatt, uten bedring av konservativ behandling. Det ble funnet indikasjon for bildediagnostikk for å utelukke underliggende sykdom. MR avbilder beinmargens bløtdelskomponent direkte og er sensitiv for påvisning av patologiske prosesser i skjelettet (5). Infiltrasjon i beinmarg ved MR er et lite spesifikt funn som ses ved flere tilstander i skjelettet (4). Et histologisk bilde med ikke-nekrotiserende granulomer, som hos vår pasient, kan forekomme ved sarkoidose, malignitet og infeksjoner (10). Diagnosen sarkoidose sikres ved biopsi (11), og det er foreslått kliniske diagnosekriterier for sarkoidose (ramme 1) (11).

Sarkoidose er en systemisk inflammatorisk sykdom av ukjent etiologi, karakterisert av patologisk granulomdanning i affiserte organ $(2,8,11)$. Patogenesen er bare delvis kartlagt 
$(12,13)$. Lungene angripes oftest, og mer enn $90 \%$ har lungeforandring $(7)$.

Beinmargsaffeksjon er sjelden, både som isolert manifestasjon eller som ledd i mer utbredt sykdom $(14,15)$. En studie fra 2014 viste at i gruppen med beinmargsaffeksjon hadde $90 \%$

affisert bekken og lumbosakralcolumna (16). Sarkoidose i beinmarg forekommer som oftest uten hematologiske avvik (17), som hos vår pasient. Smerter relatert til beinmargsaffeksjon av sarkoidose kan forekomme ved aktiv sykdom (15). Symptomatisk effekt av behandling av sarkoidose i beinmarg er ikke godt dokumentert, og prognosen avhenger av utbredelse av sykdom og grad av organpåvirkning $(16,18,19)$. Kortikosteroider vil vanligvis være førstevalg dersom behandlingsindikasjon for sarkoidose foreligger.

Funn ved PET/CT førte til mistanke om patologi i gastrointestinalkanalen, og gastroskopifunn med biopsering sammenholdt med positiv serologiprøve og påvist vevstype HLA-DQ2 gjorde at vi kunne stille diagnosen cøliaki (20). Vår pasient oppfylte fire av fem diagnostiske kriterier (ramme 2).

Cøliaki er en glutenindusert, systemisk, autoimmun sykdom (20, 21). Sykdommen blir diagnostisert både hos barn og voksne (20, 22). Det er i senere tid rettet større oppmerksomhet mot ikke-gastrointestinale symptomer og assosierte lidelser ved cøliaki (21). Studier viser at ekstra-intestinale manifestasjoner er meget vanlig (21, 22), inkludert symptomer som kan ligne revmatiske sykdommer (21). Sarkoidose og cøliaki er assosiert med bestemte vevstyper, HLA-DR3 og HLA-DQ2 (23, 24), der sistnevnte forelå hos vår pasient. En assosiasjon mellom disse to lidelsene finnes trolig $(23,24)$, og flere har foreslått å screene for cøliaki hos pasienter med sarkoidose (25). Det er også mulig at sykdommene predisponerer for hverandre ved at uttrykket av HLA økes (23). Det er en kjent sammenheng mellom ubehandlet cøliaki og intestinale kreftsykdommer, spesielt B- og T-cellelymfom.

Pasienthistorien illustrerer utfordringene ved utredning av bekkensmerter. $\emptyset \mathrm{kt}$ bruk av bildediagnostikk, og spesielt MR, vil trolig føre til flere tilfeldige, patologiske funn i beinmarg $(3,15)$. Intervensjoner hos vår pasient var glutenfritt kosthold og tverrfaglig rehabilitering. Hun hadde tidligere fors $\emptyset$ kt behandling hos fysioterapeut uten bedring av symptomer. Vi mener det er god grunn til å mistenke at det var cøliaki som bidro til slapphet og smerter i bekkenet og at overgang til glutenfri kost var nøkkelen til bedring av symptomene.

LITTERATUR:

1. Ihlebaek C, Brage S, Natvig B et al. Forekomst av muskel- og skjelettlidelser i Norge. Tidsskr Nor Lægeforen 2010; 130: 2365-8. [PubMed][CrossRef]

2. Lateef H, Patel D. What is the role of imaging in acute low back pain? Curr Rev Musculoskelet Med 2009; 2: 69-73. [PubMed][CrossRef]

3. Grønningsæter IS, Ahmed AB, Vetti N et al. Bone marrow abnormalities detected by magnetic resonance imaging as initial sign of hematologic malignancies. Clin Pract 2018; 8: 1061. [PubMed]

4. Navarro SM, Matcuk GR, Patel DB et al. Musculoskeletal imaging findings of hematologic malignancies. Radiographics 2017; 37: 881-900. [PubMed][CrossRef]

5. Moore SL, Kransdorf MJ, Schweitzer ME et al. Can sarcoidosis and metastatic bone lesions be reliably differentiated on routine MRI? AJR Am J Roentgenol 2012; 198: 1387-93. [PubMed][CrossRef]

6. Jamilloux Y, Kodjikian L, Broussolle C et al. Sarcoidosis and uveitis. Autoimmun Rev 2014; 13: 840-9. [PubMed][CrossRef]

7. Dempsey OJ, Paterson EW, Kerr KM et al. Sarcoidosis. BMJ 2009; 339: b3206. [PubMed][CrossRef]

8. Prasse A. The diagnosis, differential diagnosis, and treatment of sarcoidosis. Dtsch Arztebl Int 2016; 113: 565-74. [PubMed]

9. Promteangtrong C, Salavati A, Cheng G et al. The role of positron emission tomography-computed tomography/magnetic resonance imaging in the management of sarcoidosis patients. Hell J Nucl Med 2014; 17: 123-35. [PubMed] 
10. Yachoui R, Parker BJ, Nguyen TT. Bone and bone marrow involvement in sarcoidosis. Rheumatol Int 2015; 35: 1917-24. [PubMed][CrossRef]

11. Heinle R, Chang C. Diagnostic criteria for sarcoidosis. Autoimmun Rev 2014; 13:383-7.

[PubMed][CrossRef]

12. Vikse J, Ørn S, Jeroen de Romijn B et al. Kardial sarkoidose. Tidsskr Nor Legeforen 2018; 138. doi: 10.4045/tidsskr.17.0701. [PubMed][CrossRef]

13. Bjørnstad-Pedersen H. Sarkoidose - en sykdom med mange ansikter. Indremedisineren 2009; 2: 12-3.

14. Valeyre D, Prasse A, Nunes H et al. Sarcoidosis. Lancet 2014;383: 1155-67. [PubMed][CrossRef]

15. Zhou Y, Lower EE, Li H et al. Clinical characteristics of patients with bone sarcoidosis. Semin Arthritis Rheum 2017; 47: 143-8. [PubMed][CrossRef]

16. Sparks JA, McSparron JI, Shah N et al. Osseous sarcoidosis: clinical characteristics, treatment, and outcomes-experience from a large, academic hospital. Semin Arthritis Rheum 2014; 44:371-9.

[PubMed][CrossRef]

17. Hameed OA, Skibinska M. Scar sarcoidosis with bone marrow involvement and associated musculoskeletal symptoms. BMJ Case Rep 2011; 2011: bcro220113863. [PubMed][CrossRef]

18. Iannuzzi MC, Rybicki BA, Teirstein AS. Sarcoidosis. N Engl J Med 2007; 357: 2153-65.

[PubMed][CrossRef]

19. Patel SR. Systemic sarcoidosis with bone marrow involvement responding to therapy with adalimumab: a case report. J Med Case Rep 2009; 3: 8573. [PubMed][CrossRef]

20. Catassi C, Fasano A. Celiac disease diagnosis: simple rules are better than complicated algorithms. Am J Med 2010; 123: 691-3. [PubMed][CrossRef]

21. Laurikka P, Nurminen S, Kivelä L et al. Extraintestinal manifestations of celiac disease: Early detection for better long-term outcomes. Nutrients 2018; 10: E1015. [PubMed][CrossRef]

22. Rampertab SD, Pooran N, Brar P et al. Trends in the presentation of celiac disease. Am J Med 20o6; 119:355.e9-14. [PubMed][CrossRef]

23. Hwang E, McBride R, Neugut AI et al. Sarcoidosis in patients with celiac disease. Dig Dis Sci 2008; 53: 977-81. [PubMed][CrossRef]

24. D'Ercole C, Zullo A, Bragazzi MC et al. Sarcoidosis and coeliac disease: do not forget the association! Intern Emerg Med 2012; 7 (suppl 1): S25. [PubMed][CrossRef]

25. Gill D, Mann K, Lyons M et al. Screening of celiac disease in patients with sarcoidosis? Am J Med 2017; 130: e249-50. [PubMed][CrossRef]

Publisert: 24. april 2019. Tidsskr Nor Legeforen. DOI:10.4045/tidsskr.18.0541

Mottatt 25.6.2018, første revisjon innsendt 7.1.2019, godkjent 15.2.2019.

(C) Tidsskrift for Den norske legeforening 2020. Lastet ned fra tidsskriftet.no 